erotic pictures).

Meantime, Sherpa Stafford is slaving away at hush-hush experiments to prove Cantor's cancer theory. These are so hush-hush and so exhausting that they drive Celestine to complain about his sexual inadequacies, as she soaps his nether regions, using that four-letter word which Ken Tynan - like Carl Djerassi did not shrink to use. Eventually, Stafford succeeds and all is set for the vital letter to Nature which eventually yields the "Nobel in medicine". But not before a lot of worry and unpleasantness about the inability of Kurt Krauss, I.C.'s nasty competitor at Harvard Medical School, to repeat poor Stafford's work. Had Jerry fiddled the results? We are not really sure even when Celestine is disturbed with another boyfriend - appropriately called Roger - to learn that Jerry is to share the Nobel prize with I.C. her Auntie Paula and they all have a wonderful time - pages of it - with both I.C. and Jerry spouting T.S. Eliot in their
Celestine goes along to Stockholm with

speeches and Jerry having a nice gossip with the Swedish Queen about how the Brits use their knives and forks and eat peas.

And that's about it really, apart from some reasonably happy endings - all neatly tied up - and a final bitter letter to I.C. from poor old Krauss, who is still as sick as a parrot about not getting his Nobel prize.

What, I wonder, were Professor Djerassi's motives in writing this book? Is he condoning what he portrays? Is he saying, look, this is how it is. What a smart lot we scientists are: pushy, clever, cutting corners (nudge, nudge), getting a bit on the side (snigger, snigger), swanking about our erotic pictures and Boccherini! If he is, then the hell with it. If, on the other hand, he is saying, look, this rat race is awful, then Cantor's Dilemma is a clever, if stomach-turning, way of portraying it. $\square$

John Treherne, novelist and scientist, died on 23 September. This rumbustious review was characteristic of the writer and the man.

\section{Ideal thinking}

\section{Steven Rose}

Russian Psychology: A Critical History. By David Joravsky. Basil Blackwell: 1989. Pp. 583. £45, \$34.95.

IMAGINE a book entitled American Psychology: A Critical History, the first third of which advances that history no further than 1917, the bulk of which follows events only to the early $1930 \mathrm{~s}$, and which devotes a mere 30 pages to the years since 1953 - years that have seen such a flowering of the neural and behavioural sciences, and the transformation of our understanding of brain and behaviour. That this disproportion does not seem wholly incongruous for a Western history of Soviet psychology is of course indicative of the extraordinary interest that the first 36 years of the tortured (and torturing) relationship of Soviet communism with science has held for political philosophers, historians and scientists alike. Nor would a history of American psychology of the period (unless of course written by Mr Leo Abse, MP, the recent biographer of Britain's present Prime Minister) be likely to find space for a psychological analysis of F.D. Roosevelt, as this book offers for Stalin. But it also reveals the limits of that interest, for Stalin's death in 1953 is precisely the midway point between October 1917 and the current era, and the second half of this period should surely be as relevant and subject to historical scrutiny as the first for what claims to be, as Joravsky's book does, a comprehensive account.
The superficial view of Soviet science under Stalin sees the period straightforwardly as one in which scientific data and theory were subordinated to political ideology, typified by the Lysenko episode in genetics, often regarded as a simple count misses the passionate concern of Marxism to see itself simultaneously as science and metascience, and the equally powerful determination of an impoverished and backward country to embrace and use science in its desperate push towards modernization. Equally, an unquestioning acceptance of the Western liberal view of science as neutral and above politics, philosophy or ideology misses the opportunity to see, in that Soviet experience, a mirror of some of the problems about the place and organization of science in our own society.

A number of Western scholars have tried to move beyond this simplistic view; the Lysenko affair has been reassessed by Levins and Lewontin, by Lecourt and by Joravsky himself, while Loren Graham's comprehensive Science and Philosophy in the Soviet Union has recently been revised and republished. Joravsky's earlier essay in this direction, Soviet Marxism and Natural Science, was for a long period after its appearance in 1961 the only book on the theme in English.

The development of Soviet psychology is of particular interest. First, psychology had strong roots in pre-revolutionary Russia, stretching back through Pavlov to Sechenov. Second, the subject matter of psychology has profound bearing on theories of human nature and society, and hence a fortiori on Marxism. Third, the theoretical battle between materialism reciprocal of Nazi eugenics. Such an ac- and dualism, between reductionism and dialectics, which in many areas of science is masked or confined to the philosophers, has been and remains a vital issue of methodology and scientific practice for research in psychology and neurobiology in the West as well as the East. Finally, the vast experiment in social engineering in the Soviet Union during the first half of its post-revolutionary history was directed to the creation of "the new socialist man [sic]", and one might well have expected that psychologists would find themselves mobilized to this task.

Thus, from the $1920 \mathrm{~s}$ on, Soviet neurophysiologists, psychologists and philosophers struggled to develop an adequate theory of the dialectic of brain and society in the production of mind, and an adequate practice of pedology (educational science) and psychotechnics based upon that theory. This struggle with some of the deepest conceptual and methodological problems with which science has to cope, produced responses ranging from the hard-line physiological materialism of Pavlov almost until his last days, through the pioneering work on the social production of mind by the polymath Vygotsky and the later development of neuropsychology by Luria. In the next generation it produced Rubinshtein's activity theory, Anokhin's functional systems approach, the work of Beritashvili, Leontiev and Orbeli, as well as a strong school of functional neurochemistry.

And of course, the work of nearly all of these scientists was punctuated by endless crises, from the desperate economic situation and famine of the early years (to be repeated during the 'Great Patriotic War'), through the increasing tendency to solve scientific disputes by administrative fiat - with all the dread consequences that that entailed - from the 1930 s to well beyond the death of Stalin. The debates in psychology seem not to have been quite so literally life-and-death affairs as they were in genetics, although Joravsky lists many victims of the Gulag. True, after 1945 Pavlov was for a time elevated to stardom within Stalin's pantheon, and recantation was forced upon those of his pupils and disciples whose greater understanding of brain physiology and psychology (to say nothing of their better Marxism) led them to deviate from the line of their late master. Even so, the debates in the 'Pavlov sessions' for psychologists, physiologists and psychiatrists in 1950,1951 and 1952 seem much less staged and more open than the notorious 1948 session of the Agricultural Academy which saw the destruction of genetics and the apotheosis of Lysenko.

Just why this should be so would seem to be a question of some significance perhaps it was because of the stronger research and philosophical traditions of Soviet psychology and physiology; 
perhaps because the declared luminary of the subject, Pavlov, unlike Lysenko, was long dead; perhaps because there was a greater urgency to solve the practical crisis in agriculture than to employ science instead of naked coercion in the production of the new socialist man.

Oddly, however, although Joravsky documents the debates extensively he makes no great effort to address these

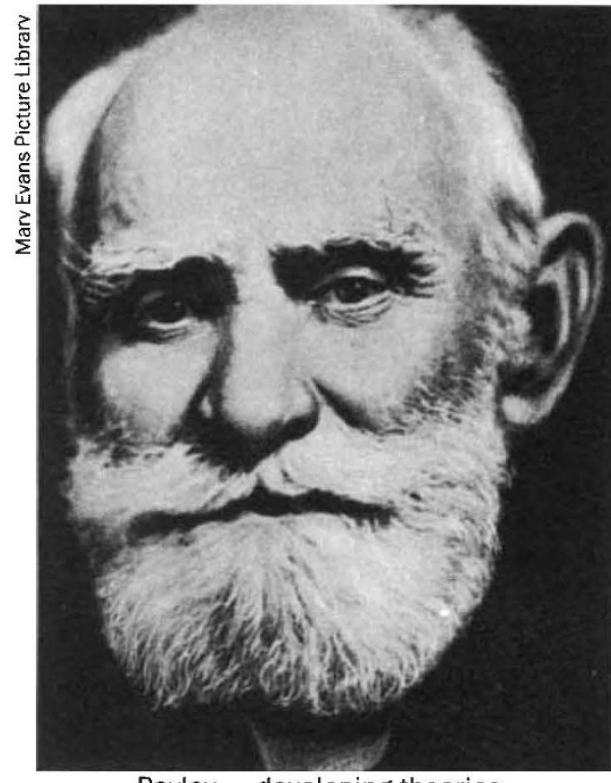

Pavlov - developing theories.

broader questions, and the omission is characteristic of a book which in the last analysis yields much less than it promises. Joravsky is not an internalist historian; he is not so much concerned with experimental findings which led Pavlov, Kornilov, Vygotsky or Luria to their theoretical positions, or with the ebb and flow of the scientific debate; rather, he is offering us a metahistory of psychology, an account of the ways in which the leading protagonists of the discipline in the 1920s and 1930s sought to locate their theories within the swirling currents of the party-led attempts to establish a Marxist orthodoxy. In effect this book is not so much a history of Russian psychology but of psychology in Russia.

The author's scholarship is formidable, and the phrenology he has created whilst denied entry into the Soviet Union or access to many key papers is impressive, despite the fact that the book has, on internal evidence, been a very long time in the making and is the weaker for it. Nonetheless, Joravsky creates the strong impression of being in the last analysis rather bored by the scientific questions which dominate the professional lives of the subjects of his history. A reader of this book who opened it knowing nothing even of Pavlov's key experiments and theories would close it being little the wiser, though he would have learned that Pavlov was a vain, opinionated and authoritarian little man whom Joravsky doesn't like very much. Indeed, Joravsky finds it diffi- cult to observe admirable qualities in almost any of his protagonists. If they don't speculate about the broader significance of their results he finds them narrow technocrats; if they do, they are shallow philosophers, or time-servers who would mould their theories to political exigencies. The treatment - or rather dismissal - of Rubinshtein, Luria and Anokhin in this way is inexcusable in however critical a history. A couple of what Joravsky would probably regard as boringly internalist histories of Russian psychology were published some years ago and do a much more useful job in this regard.

Joravsky would probably respond by saying he wasn't trying to write that sort of book at all. His elegantly worked-over prose, full of ironic asides, musing selfreflections and studied ambiguities may in some ways best be read as an unspoken historiographic debate with what has become known as the Edinburgh school in the sociology, history and philosophy of science, which seeks to reduce debates

\section{Pens and petals}

\section{Ray Desmond}

The Art of Botanical Illustration: The Classic Illustrators and Their Achlevements from 1550 to 1900 . By Lys de Bray. Christopher Helm, London: 1989. Pp. 192. £25.

THE drawing of flowers - whether for research, decoration or simply for pleasure - is the subject of an impressive literature. A distinguished pioneer in this field was Agnes Arber, whose survey of printed herbals and their woodcut illustrations, Herbals: Their Origin and Evolution (1912; 2nd edn, 1986), has become a classic. Another well-known and authoritative text is Wilfrid Blunt's The Art of Botanical Illustration (1950; 3rd edn, 1955). His Illustrated Herbal (1980), written in conjunction with Sandra Raphael, complements Arber's volume in dealing primarily with the manuscript herbal.

These are just three of many books dealing with aspects of botanical art that have appeared during the course of this century, many of them during the 1970s and 1980s. Artists such as Leonardo de Vinci, Albrecht Dürer, Jacques le Moyne, Georg Ehret, Sydney Parkinson, PierreJoseph Redouté, Mrs Delaney and Marianne North have all been the subject of monographs. Other authors have looked at flower drawing and painting from the point of view of the bibliographer and the printer, while exhibitions, museums and auction houses have each generated accounts of specific collections.

Any new book in this area has to be about fact and theory in science to a reflection of the interests - the social origins and positions - of the main characters. Joravsky's own interest, as the doyen of the history of Soviet science in the West, remains somewhat unstated. He offers himself as an outsider, neither a sympathizer with nor enemy to communism, an olympian observer and chronicler. But in practice he cannot sustain such detachment; his language constantly lets him down, as when, for all his reading of the Marxist classics, confronted with that robust concept 'working class' he routinely bowdlerizes it to 'lower class'. A real critical history of Soviet psychology, which transcends internalist-externalist boundaries, and helps us to rescue its rational kernel from both Eastern and Western ideological trappings, remains to be written. It will be worth waiting for.

Steven Rose is in the Brain and Behaviour Research Group, Department of Biology, Open University, Walton Hall, Milton Keynes MKT GAA, UK.

judged against the high standards set by some of its predecessors. Even though Lys de Bray's The Art of Botanical Illustration has no pretensions to original research, aimed as it is at a general readership, and is generously illustrated with colour plates, it is an unhappy piece of work. There are frequent signs of haste in its preparation and the text bristles with errors - misspellings, mistakes in dates of birth and death and in dates of publication - some of which are doubtless due to careless proof reading.

These slips are irritating but others are more misleading. Jacobus van Huysum was employed by Sir Robert (not Horace) Walpole; William Kilburn did not contribute any plates to the Botanical Magazine; B. Maund and E.D. Smith were connected with the Botanic Garden not the Botanical Register; J.N. Fitch lithographed plates for the Botanical Magazine but he did not succeed his uncle as artist to the journal. There is no evidence that William Kent landscaped the Prince of Wales's garden at Kew (which was much more than the 11 acres stated by Ms de Bray); Princess Augusta did not extend her property at Kew after the death of Queen Caroline; and W.T. Aiton did not resign from Kew in 1841, he merely relinquished control of the small botanical garden there. This is not an exhaustive list.

It is unfortunate that the author should have chosen The Art of Botanical Illustration as her title because it invites comparison with Wilfrid ('Wilfred' in Ms de Bray's book) Blunt's volume. Clearly, though, it poses no threat to the status of the earlier work.

Ray Desmond is at the Royal Botanic Gardens, Kew, Richmond, Surrey TW9 3AB, UK. 